IUCrJ

ISSN 2052-2525

BIOLOGY|MEDICINE

Received 15 October 2020

Accepted 30 November 2020

Edited by Z.-J. Liu, Chinese Academy of Sciences, China

₹ These authors contributed equally to this work.

Keywords: streptavidin; biotin; antifungal activity; Streptomyces cinnamonensis; self-binding.

PDB references: streptavidin $\mathrm{C} 1$, mature form, 7cq0; complex with D-biotin, $7 \mathrm{cpz}$

Supporting information: this article has supporting information at www.iucrj.org

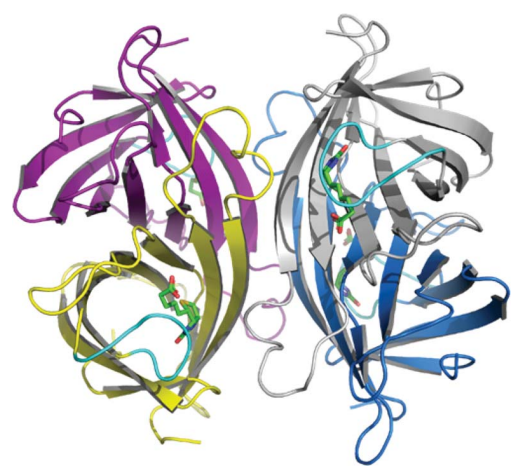
OPEN $\odot$ ACCESS

\section{Insights into the structure of mature streptavidin C1 from Streptomyces cinnamonensis reveal the self-binding of the extension C-terminal peptide to biotin-binding sites}

\author{
Byeong Jun Jeon, ${ }^{a} \ddagger$ Sulhee Kim, ${ }^{b} \ddagger$ Min-Seok Kim, ${ }^{b}$ Ji-Ho Lee, ${ }^{b}$ Beom Seok Kim ${ }^{a} *$ \\ and Kwang Yeon Hwang ${ }^{b_{*}}$
}

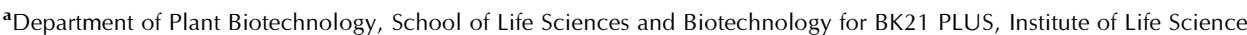
and Natural Resources, Korea University, 145 Anam-ro, Seongbuk-gu, Seoul 02841, South Korea, and 'bepartment of Biotechnology, School of Life Sciences and Biotechnology for BK21 PLUS, Institute of Life Science and Natural Resources, Korea University, 145 Anam-ro, Seongbuk-gu, Seoul 02841, South Korea. *Correspondence e-mail: biskim@korea.ac.kr, chahong@korea.ac.kr
\end{abstract}

The members of the avidin protein family are well known for their high affinity towards D-biotin and their structural stability. These properties make avidins a valuable tool for various biotechnological applications. In the present study, two avidin-like biotin-binding proteins (named streptavidin $\mathrm{C} 1$ and $\mathrm{C} 2$ ) from Streptomyces cinnamonensis were newly identified while exploring antifungal proteins against Fusarium oxysporum f. sp. cucumerinum. Streptavidin C1 reveals a low correlation (a sequence identity of approximately 64\%) with all known streptavidins, whereas streptavidin C2 shares a sequence identity of approximately $94 \%$ with other streptavidins. Here, the crystal structures of streptavidin $\mathrm{C} 1$ in the mature form and in complex with biotin at 2.1 and $2.5 \AA$ resolution, respectively, were assessed. The overall structures present similar tetrameric features with $D_{2}$ symmetry to other (strept)avidin structures. Interestingly, the long $\mathrm{C}$-terminal region comprises a short $\alpha$-helix (C-Lid; residues 169-179) and an extension C-terminal peptide (ECP; residues 180-191) which stretches into the biotin-binding sites of the same monomer. This ECP sequence $\left({ }^{180}\right.$ VTSANPPAS $\left.^{188}-\right)$ is a newly defined biotin-binding site, which reduces the ability to bind to (strept)avidin family proteins. The novel streptavidin C1 could help in the development of an engineered tetrameric streptavidin with reduced biotin-binding capacity as well as other biomaterial tools.

\section{Introduction}

Avidin from chicken (Gallus gallus) egg white is a naturally glycosylated protein, whereas streptavidin is a nonglycosylated protein secreted by Streptomyces avidinii. These proteins have long been studied for a diverse array of medical and biotechnological applications. Avidin and bacterial streptavidin, which have a homotetrameric quaternary structure, are known to exhibit an extremely high affinity $\left(K_{\mathrm{d}}\right.$ values of approximately $10^{-15} M$ ) for biotin (Green, 1990). The highaffinity avidin-biotin system is unique, and its versatile applications are primarily based on the chemistry of biotin conjugation (Diamandis \& Christopoulos, 1991). These applications include protein detection, microscopy, diagnosis, drug delivery and others (Laitinen et al., 2007; Lesch et al., 2010). Although highly useful, the aforementioned system has certain limitations, which frequently result from the homotetrameric assembly of the four high-affinity biotin-binding 
sites, with the tight biotin binding making streptavidin unsuitable for the affinity purification of biotinylated molecules. It would be ideal to develop an engineered streptavidin with a reversible biotin-binding capability. However, unexpected cross-linking could occur, and precise quantification is impossible as the binding-site occupancy cannot be verified. Several studies have been carried out to minimize and alter the tetrameric assembly in order to decrease the stoichiometry of avidins (Howarth et al., 2006; Laitinen et al., 2006). Attempts to minimize the tetrameric configuration of avidins via rational design have been less successful (DeMonte et al., 2013; Hytönen et al., 2005; Laitinen et al., 2006; Lee et al., 2016; Nordlund, Hytönen, Hörhä et al., 2005). To date, numerous proteins belonging to the avidin family have been explored, including those originating from various organisms ranging from bacteria to fungi, birds, reptiles and fish (Chaiet \& Wolf, 1964; Green, 1990; Keinänen et al., 1994; Määttä et al., 2009; Takakura et al., 2009; Taskinen et al., 2013). Despite their functional similarities, streptavidin and avidin present different amino-acid sequences in their primary structures. The degree of sequence identity between these proteins is approximately $30 \%$. Avidin has a high isoelectric point $(\mathrm{pI}=$ $10.5)$, whereas streptavidin has a low isoelectric point $(\mathrm{pI}=$ 6.1-7.5) compared with avidin. The high $\mathrm{pI}$ of avidin can cause nonspecific binding to various biological components, thus limiting its use in specific applications. On the other hand, the amino-acid sequences of streptavidin V1 and streptavidin V2 purified from $S$. venezuelae were identical to that of the original streptavidin, except for the first and ninth amino acids, respectively (Bayer et al., 1995).

Within the tetrameric assembly of the avidins, three types of monomer-monomer interactions (Livnah et al., 1993) exist. The 1-2 interaction involves a tryptophan residue (position 110 in egg-white avidin) that is donated from one monomer to the biotin-binding site of the adjacent monomer. The 1-3 interaction is relatively small and involves approximately 3-4 participating residues from each monomer. The 1-4 interaction is the most important, with a contact area of 1200 $1500 \AA^{2}$ per monomer, and is also termed a sandwich-like interaction (Meir et al., 2009). Recently, the discovery of highaffinity dimeric avidins from bacterial sources, including bacterial avidin-like proteins from Rhizobium etli (rhizavidin), Shewanella denitrificans (shwanavidin) and Hoeflea phototrophica DFL-43 (hoefavidin), has been reported, although the high affinity for biotin was maintained in these proteins (Avraham et al., 2015; Helppolainen et al., 2007; Meir et al., 2009, 2012). Structural analyses of these proteins revealed that they maintain the unique basic features of the avidin family, in which each monomer displays a near-identical topology and quaternary structure, with similar interactions to the 1-4 interaction of the tetrameric avidins, thus forming a sandwichlike dimer. The dimeric structure lacks the 1-2 and 1-3 interactions and the critical crossover tryptophan residue that distinguish the tetrameric avidins.

To elucidate the strategies to be applied in engineering streptavidin with biotin-binding ability, it is crucial to understand the unique structural features of (strept)avidin, its biotin-binding pockets and the quaternary interfaces. In the present study, we discovered two novel avidin-like biotinbinding proteins (named streptavidins $\mathrm{C} 1$ and $\mathrm{C} 2$ ) from $S$. cinnamonensis while exploring antifungal proteins against Fusarium oxysporum f. sp. cucumerinum. Interestingly, streptavidin $\mathrm{C} 1$ reveals a low correlation (a sequence identity of approximately $64 \%$ ) with all known streptavidins, whereas streptavidin C2 shares a sequence identity of approximately $94 \%$ with other streptavidins. We determined crystal structures of streptavidin C1 (191 amino acids) in the mature form and as a complex with biotin at 2.1 and $2.5 \AA$ resolution, respectively. The well ordered long C-terminus comprises a short $\alpha$-helix and a C-terminal tail which stretches into the biotin-binding sites of the same monomer. The structures clearly revealed unique structural and compositional features in comparison with other avidin-like proteins. Moreover, we further describe the structural analysis and biochemical characterization of streptavidin $\mathrm{C} 1$. This novel member of the (strept)avidin family could be used in diverse biotin-based nanotechnologies or may act as a building block in the production of new bioinspired materials.

\section{Experimental procedures}

2.1. Identification, production and purification of antifungal proteins

S. cinnamonensis strain KPP02129 was grown on tryptic soy agar plates for three days at $28^{\circ} \mathrm{C}$. A single colony on the plate was transferred to a 11 Erlenmeyer flask containing $100 \mathrm{ml}$ tryptic soy broth (TSB) at $28^{\circ} \mathrm{C}$ for three days on a rotary shaker at $200 \mathrm{rev} \mathrm{min}^{-1}$. After three days, modified TSB $(4 \mathrm{~g}$ tryptone, $0.5 \mathrm{~g}$ soytone, $2.5 \mathrm{~g}$ dextrose, $5 \mathrm{~g}$ sodium chloride, $2.5 \mathrm{~g}$ dipotassium hydrogen phosphate in 11 water) medium (11) was inoculated with $1 \%(v / v)$ of the preculture and incubated at $28^{\circ} \mathrm{C}$ on a rotary shaker at $200 \mathrm{rev} \mathrm{min}^{-1}$ for five days. The 11 culture was centrifuged at $8000 \mathrm{~g}$ for $30 \mathrm{~min}$ to separate the cells from the broth, and solid ammonium sulfate was then added to the culture broth to $95 \%$ saturation at $4^{\circ} \mathrm{C}$. The resulting precipitate was harvested via centrifugation at $13000 \mathrm{~g}$ for $30 \mathrm{~min}$ at $4^{\circ} \mathrm{C}$. The pellet was dissolved in approximately $20 \mathrm{ml} 20 \mathrm{mM}$ Tris- $\mathrm{HCl} \mathrm{pH} 8.0$ and dialyzed with the same buffer overnight three times. The resulting protein solution was loaded onto a $5 \mathrm{ml}$ HiTrap Q HP column (GE Healthcare Bio-Sciences, Uppsala, Sweden) equilibrated with $20 \mathrm{~m} M$ Tris- $\mathrm{HCl} \mathrm{pH} \mathrm{8.0.} \mathrm{After} \mathrm{washing} \mathrm{the} \mathrm{column} \mathrm{with}$ the same buffer, the protein was eluted with a stepwise gradient of increasing $\mathrm{NaCl}$ concentration $(100,150,250,300$ and $400 \mathrm{~m} M$ and $1 M \mathrm{NaCl}$ ). The eluted fractions were assayed for antifungal activity against $F$. oxysporum $\mathrm{f}$. sp. cucumerinum (FOC) using a paper-disk assay and were then separated via SDS-PAGE on $15 \%$ gels. Proteins were stained with Coomassie Brilliant Blue G-250 or by the silver-staining method. The band containing the active fraction was excised. Protein identity analysis of the excised band was performed using a UHPLC-MS/MS system (Thermo Scientific Dionex Ultimate 3000) equipped with an analytical column (Acclaim 
PepMap RSLC $50 \mu \mathrm{m} \times 15 \mathrm{~cm}$, nanoViper, C18, $2 \mu \mathrm{m}, 100 \AA$ A; Thermo Scientific).

\subsection{Primary-structure analysis and protein expression}

Avidin-like genes were amplified by PCR using the DNA of S. cinnamonensis strain KPP02129 as a template. The primer set used for PCR included C1F-NdeI and C1R-XhoI or C2FNdeI and C2R-XhoI (Supplementary Table S1). $2 \times$ PreMIXHF (Macrogen Co., Seoul, South Korea) was then added to the reaction. The amplification was performed with an initial denaturation step at $95^{\circ} \mathrm{C}$ for $5 \mathrm{~min}$ followed by 30 cycles of denaturation at $94^{\circ} \mathrm{C}$ for $1 \mathrm{~min}$, annealing at $60^{\circ} \mathrm{C}$ for $1 \mathrm{~min}$ and extension at $72^{\circ} \mathrm{C}$ for $90 \mathrm{~s}$, and a final extension at $72^{\circ} \mathrm{C}$ for $3 \mathrm{~min}$. The amplified products were cloned into the pTOP TA V2 vector (Macrogen) for TA cloning and were sequenced. The resulting sequences and the avidin-related protein sequences were aligned with ClustalW (https://www.genome.jp/ tools-bin/clustalw). ESPript (http://espript.ibcp.fr/ESPript/ cgi-bin/ESPript.cgi) was used for alignment, visualization and manipulation. The amplified streptavidins $\mathrm{C} 1$ and $\mathrm{C} 2$ were cloned into pET-21a vector using the NdeI and XhoI restriction enzymes. Moreover, C-terminal deletion mutants of streptavidin $\mathrm{C} 1$ ( $\Delta \mathrm{C} 1$, amino acids $1-161$, and $\Delta \mathrm{C} 2$, amino acids 1-158) were cloned into the same vector. The recombination plasmids were transformed into Escherichia coli strain BL21 harboring one of the expression vectors. The cells were grown in Luria-Bertani (LB) broth containing ampicillin at $37^{\circ} \mathrm{C}$ until late $\log$ phase $\left(\mathrm{OD}_{600}=0.6-0.8\right)$. The cultures were induced with $1 \mathrm{~m} M$ isopropyl $\beta$-D-1-thiogalactopyranoside (IPTG) and then shaken for a further $4 \mathrm{~h}$ at $37^{\circ} \mathrm{C}$ or $16 \mathrm{~h}$ at $18^{\circ} \mathrm{C}$. The cells were harvested via centrifugation and tested for solubility.

\subsection{Protein production and purification}

Expression of all of the recombinant proteins was induced with $1 \mathrm{~m} M$ IPTG for $16 \mathrm{~h}$ at $18^{\circ} \mathrm{C}$ in LB medium containing ampicillin. After harvesting via centrifugation at $6900 \mathrm{~g}$ for $1 \mathrm{~h}$, the total proteins were resuspended in a buffer consisting of $20 \mathrm{~m} M$ Tris-HCl pH 8.0, $100 \mathrm{~m} M \mathrm{NaCl}, 2 \mathrm{~m} M \beta$-mercaptoethanol and disrupted by sonication. Cell debris was removed via centrifugation at $9500 \mathrm{~g}$ at $4^{\circ} \mathrm{C}$ for $1 \mathrm{~h}$. The supernatant was passed through an Ni-NTA affinity column ( $5 \mathrm{ml}$ HisTrap HP, GE Healthcare) equilibrated with binding buffer $(20 \mathrm{~m} M$ Tris- $\mathrm{HCl} \mathrm{pH} 8.0,100 \mathrm{~m} M \mathrm{NaCl}, 2 \mathrm{~m} M \beta$-mercaptoethanol) and then eluted with elution buffer $(20 \mathrm{~m} M$ Tris- $\mathrm{HCl} \mathrm{pH} 8.0$, $100 \mathrm{~m} M \mathrm{NaCl}, 2 \mathrm{~m} M \beta$-mercaptoethanol, $500 \mathrm{~m} M$ imidazole). Fractions were examined using SDS-PAGE and those that contained protein were pooled. The protein was further purified via anion-exchange chromatography and eluted with a linear $\mathrm{NaCl}$ gradient in $20 \mathrm{~m} M$ Tris- $\mathrm{HCl} \mathrm{pH} 8.0,2 \mathrm{~m} M$ dithiothreitol (DTT). The purified protein was concentrated using 10K Amicon ultracentrifugal filters (Millipore, Bedford, Massachusetts, USA) and further purified via size-exclusion chromatography using a Superdex 200 26/60 column (GE Healthcare, Little Chalfont, UK) with a final buffer consisting of $20 \mathrm{~m} M$ Tris- $\mathrm{HCl}$ pH 8.0, $100 \mathrm{~m} M \mathrm{NaCl}, 2 \mathrm{~m} M$ DTT.

\subsection{In vitro antifungal assay}

The streptavidin $\mathrm{C} 1$ and $\mathrm{C} 2$ proteins were assayed to evaluate their antifungal activity against FOC using a 96-well plate. Various concentrations of the proteins $\left(1-80 \mu \mathrm{g} \mathrm{ml}^{-1}\right)$ and conidia suspension $\left(1.5-2.0 \times 10^{3}\right)$ were applied to each well of the 96-well plate containing $100 \mu$ l half-strength potato dextrose broth. After incubation at $28^{\circ} \mathrm{C}$ for $72 \mathrm{~h}$, the plate was visually inspected for concentrations that inhibited fungal growth. To assess whether excess biotin would abolish the activity of streptavidins $\mathrm{C} 1$ and $\mathrm{C} 2$, D-biotin $\left(4 \mu \mathrm{g} \mathrm{ml}^{-1}\right)$ was added.

\subsection{Thermal stability}

To determine thermal stability, the proteins $\left(0.1 \mathrm{mg} \mathrm{ml}^{-1}\right)$ were combined with $1 \times$ SDS sample buffer consisting of $50 \mathrm{~m} M$ Tris- $\mathrm{HCl} \mathrm{pH} 6.8,3 \% \beta$-mercaptoethanol, $1 \%(w / v)$ SDS, $10 \%$ glycerol and were incubated for $20 \mathrm{~min}$ at various temperatures $\left(25,50,60,70,75,80,90\right.$ and $\left.100^{\circ} \mathrm{C}\right)$. The proteins were also incubated with or without $\beta$-mercaptoethanol in $1 \times$ SDS sample buffer at room temperature (RT) or at $95^{\circ} \mathrm{C}$ in the absence and presence of biotin $\left(1 \mathrm{mg} \mathrm{ml}^{-1}\right)$. The reaction mixtures were then subjected to SDS-PAGE. To evaluate the transition temperature, the proteins were evaluated in a manner in which half of the proteins were tetrameric and other half were monomeric in the absence and presence of biotin. Streptavidin C1, streptavidin C2, streptavidin and avidin were diluted with PBS containing $0.05 \%$ Tween 20 (PBS-T) to a concentration of $1 \mathrm{mg} \mathrm{ml}^{-1}$ for Tycho NT.6 experiments. The final concentration of D-biotin was $4 \mathrm{mg} \mathrm{ml}^{-1}$. The samples were then loaded as duplicates into Tycho NT.6 capillaries (NanoTemper Technologies, Munich, Germany; catalog No. TY-C001). The temperature-inflection values $\left(T_{\mathrm{i}}\right)$ were obtained via automated data analysis.

\subsection{Analysis of strepavidin-biotin interactions via microscale thermophoresis}

Microscale thermophoresis (MST) assays were performed to study the protein-ligand interaction using a Monolith NT.115 instrument (NanoTemper Technologies). Recombinant streptavidin C1-His, streptavidin C2-His, streptavidin-His (ab78833), $\Delta \mathrm{C} 1$-His and $\Delta \mathrm{C} 2$-His proteins were labeled using the Monolith His-Tag Labeling Kit RED-tris-NTA 2nd Generation kit according to the manufacturer's instructions. Nonlabeled biotin at increasing concentrations (0.3052$10000 \mathrm{pM}$ ) in PBS-T was incubated for $10 \mathrm{~min}$ at room temperature with $200 \mathrm{p} M$ labeled streptavidin-His. Moreover, nonlabeled C-Lid_ECP or ECP in PBS-T buffer at increasing concentrations (2.4414-80 $000 \mathrm{nM}$ ) was incubated for $10 \mathrm{~min}$ at room temperature with $200 \mathrm{n} M$ labeled $\Delta \mathrm{C} 1$-His and $\Delta \mathrm{C} 2$ His. The amino-acid sequences of C-Lid_ECP and ECP were synthesized as $-{ }^{169}$ SAADVEKARQLGVTSANPPASDGE ${ }^{191}$ and $-{ }^{178}$ LGVTSANPPASDGE ${ }^{191}-$, respectively (Peptron, Daejeon, South Korea). Thereafter, the samples were loaded into capillaries (Mo-Ko22 Monolith NT.115) and were evaluated at $25^{\circ} \mathrm{C}$ with $40 \%$ LED power and $60 \%$ MST power. The results were processed using $M O$ Affinity Analysis and 
GraphPad Prism. Each measurement was performed in triplicate at the same MST power.

\subsection{Size-exclusion chromatography with multi-angle light scattering (SEC-MALS)}

SEC-MALS experiments were performed using a fast protein liquid-chromatography system (GE Healthcare) connected to a Wyatt MiniDAWN TREOS MALS instrument and a Wyatt Optilab rEX differential refractometer. A Superdex 200 10/300 GL (GE Healthcare) gel-filtration column pre-equilibrated with $20 \mathrm{~m} M$ Tris- $\mathrm{HCl} \mathrm{pH}$ 8.0, $100 \mathrm{~m} M \mathrm{NaCl}, 2 \mathrm{~m} M$ DTT was normalized using bovine serum albumin. The individual proteins (streptavidin $\mathrm{C} 1$ and $\mathrm{C} 2$ and the C-terminal deletion mutants $\Delta \mathrm{C} 1$ and $\Delta \mathrm{C} 2$ ) were prepared separately by the methods described earlier and were injected $\left(1-2 \mathrm{mg} \mathrm{ml}^{-1}, 0.25 \mathrm{ml}\right)$ at a flow rate of $0.8 \mathrm{ml} \mathrm{min}^{-1}$. The data were analyzed using the Zimm model for fitting static light-scattering data and were represented using an EASI graph with a UV peak in the ASTRA $V$ software (Wyatt).

\subsection{MALDI-TOF mass-spectrometric analysis}

Mass spectra of recombinant streptavidin $\mathrm{C} 1$ were measured via matrix-assisted laser desorption/ionization timeof-flight mass spectrometry (MALDI-TOF MS; eMass, Seoul, South Korea). The protein was dissolved in $40 \%$ acetonitrile at a concentration of $20 \mathrm{mg} \mathrm{ml}^{-1}$ with $0.2 \%$ trifluoroacetic acid and was purified by ZipTip C4 (Millipore). After using a dry vacuum pump and centrifugal evaporator, sinapinic acid was added to the sample as the matrix solution. The sample was applied to a MALDI plate and subjected to MALDI-TOF MS.

\subsection{Crystallization and data collection}

Crystals of streptavidin were grown by the hanging-drop vapor-diffusion method at $20^{\circ} \mathrm{C}$ with a crystallization buffer consisting of $50 \mathrm{~m} M$ bis-Tris $\mathrm{pH} 6.5,28 \%$ pentaerythritol ethoxylate (15/4 EO/OH), $150 \mathrm{~m} M$ ammonium sulfate. The protein solution (approximately $13 \mathrm{mg} \mathrm{ml}^{-1}$ ) consisted of $20 \mathrm{~m} M$ Tris- $\mathrm{HCl} \mathrm{pH}$ 8.0, $100 \mathrm{~m} M$ sodium chloride, $2 \mathrm{~m} M$ DTT. The streptavidin protein was incubated with $3 \mathrm{~m} M$ D-biotin for $4 \mathrm{~h}$ at $4^{\circ} \mathrm{C}$ for cocrystallization and was then crystallized. The streptavidin crystals were formed at $20^{\circ} \mathrm{C}$ using $1 \mu \mathrm{l}$ well solution, $0.2 \mathrm{M}$ potassium thiocyanate, 20\% PEG 3350 and $1 \mu \mathrm{l}$ protein solution. Diffraction data were collected on BL-11C at Pohang Accelerator Light Source, Pohang, South Korea. All collected images were processed and scaled with the HKL-2000 package (Otwinowski \& Minor, 1997).

\subsection{Structure determination and refinement}

Streptavidin crystals in the mature form and in complex with D-biotin belonged to the tetragonal space group $P 4_{2} 2_{1} 2$, with unit-cell parameters $a=b=58.442, c=78.492 \AA$ and $a=b=57.938, c=74.729 \AA$, respectively. The asymmetric unit contained one molecule (Supplementary Fig. S5). The initial structure of streptavidin $\mathrm{C} 1$ was resolved by molecular
Table 1

Data-collection and refinement statistics.

Values in parentheses are for the highest resolution shell.

\begin{tabular}{|c|c|c|}
\hline & $\begin{array}{l}\text { Streptavidin C1 } \\
\text { (PDB entry 7cq0) }\end{array}$ & $\begin{array}{l}\text { Streptavidin C1, D-biotin } \\
\text { complex (PDB entry } 7 \mathrm{cpz} \text { ) }\end{array}$ \\
\hline \multicolumn{3}{|l|}{ Data collection } \\
\hline Space group & $P 4_{2} 2_{1} 2$ & $P 4_{2} 2_{1} 2$ \\
\hline$a, b, c(\AA)$ & $58.442,58.442,78.492$ & $57.938,57.938,74.729$ \\
\hline$\alpha, \beta, \gamma\left({ }^{\circ}\right)$ & $90,90,90$ & $90,90,90$ \\
\hline Resolution $(\AA)$ & $41.54-2.10(2.14-2.10)$ & $41.02-2.50(2.54-2.50)$ \\
\hline Completeness (\%) & $99.4(87.7)$ & $99.7(100)$ \\
\hline Mulitplicity & $22.2(12.4)$ & $24.7(26.1)$ \\
\hline$\langle I / \sigma(I)\rangle$ & $6.3(0.9)$ & $7.5(1.9)$ \\
\hline$R_{\text {merge }}(\%) \dagger$ & $6.6(49.1)$ & $6.7(18.9)$ \\
\hline \multicolumn{3}{|l|}{ Refinement statistics } \\
\hline Resolution (§) & $46.88-2.03$ & $41.02-2.50$ \\
\hline \multicolumn{3}{|l|}{$B$ factors $\left(\AA^{2}\right)$} \\
\hline Average & 31.34 & 28.57 \\
\hline Protein & 30.93 & 27.68 \\
\hline Ligands & & 25.39 \\
\hline Solvent & 35.81 & 36.69 \\
\hline \multicolumn{3}{|l|}{ R.m.s. deviations } \\
\hline Bond lengths $(\AA)$ & 0.002 & 0.002 \\
\hline Bond angles $\left({ }^{\circ}\right)$ & 0.536 & 0.587 \\
\hline \multicolumn{3}{|c|}{ Ramachandran plot (\%) } \\
\hline Favored & 97.10 & 98.31 \\
\hline Allowed & 2.90 & 1.69 \\
\hline Outliers & 0.00 & 0.00 \\
\hline
\end{tabular}

$\dagger R_{\text {merge }}=\sum_{h k l} \sum_{i}\left|I_{i}(h k l)-\langle I(h k l)\rangle\right| / \sum_{h k l} \sum_{i} I_{i}(h k l)$.

replacement with Phaser (McCoy et al., 2007) using partial models (PDB entry 2bc3; Le Trong et al., 2006) as search models in the CCP4 suite (Winn et al., 2011). Model building was performed automatically with the AutoBuild (Langer et al., 2008) module in Phenix (Liebschner et al., 2019) and manually with Coot (Emsley et al., 2010). The final model refinement was performed in REFMAC (Murshudov et al., 2011). The final models were validated using MolProbity (Chen et al., 2010) and had $R$ values of $R_{\text {work }}=20.3 \%$ and $R_{\text {free }}=22.6 \%$ for mature streptavidin C1 and $R_{\text {work }}=19.1 \%$ and $R_{\text {free }}=23.3 \%$ for the complex with biotin. The datacollection and structure-refinement statistics are summarized in Table 1. All structural figures were generated in $P y M O L$ (Schrödinger). The structure-factor and coordinate files have been deposited in the Protein Data Bank with accession codes $7 \mathrm{cq} 0$ and $7 \mathrm{cpz}$.

\section{Results and discussion}

\subsection{Identification of antifungal proteins from}

\section{S. cinnamonensis strain KPP02129}

Firstly, for the identification of potent antifungal proteins against $F$. oxysporum f. sp. cucumerinum (FOC), we used the culture broth of $S$. cinnamonensis strain KPP02129 (deposited in GenBank as accession No. MT890000) cultured in modified TSB. To identify its active ingredients, we performed conventional ammonium sulfate precipitation and dialysis as described in Section 2. Thereafter, two active fractions, eluted fraction 1 (ET1; $20 \mathrm{~m} M$ Tris- $\mathrm{HCl} \mathrm{pH} 8.0,100 \mathrm{~m} M \mathrm{NaCl}, 2 \mathrm{~m} M$ DTT) and eluted fraction 2 (ET2; $20 \mathrm{~m} M$ Tris- $\mathrm{HCl} \mathrm{pH} 8.0$, 
$150 \mathrm{~m} M \mathrm{NaCl}, 2 \mathrm{~m} M$ DTT), exhibited antifungal activity against FOC [Figs. 1(a) and 1(b)]. The bands were excised from a Coomassie-stained gel and were treated with trypsin for protein identification (eMass, Seoul, South Korea). Eventually, via protein identity analysis, the antifungal proteins were identified to be avidin-family proteins. To characterize these new avidin-like proteins (named streptavidin $\mathrm{C} 1$ and $\mathrm{C} 2$ ), the full-length open reading frame (ORF) of streptavidin C1 (Met1-Glu191) from gDNA of S. cinnamonensis was cloned into the expression vector pET21a. The recombinant protein was expressed in a soluble form in E. coli BL21 (DE3) cells. The final purified protein was concentrated and injected onto a Superdex 200 26/60 gelfiltration column [Fig. 1(c)]. After purification, streptavidins $\mathrm{C} 1$ and $\mathrm{C} 2$ were subjected to size-exclusion chromatography using multi-angle light scattering (SEC-MALS) to evaluate the exact molar mass and root-mean-square (r.m.s.) radius $R_{\mathrm{g}}$ in solution. The molecular masses determined by SEC-MALS are approximately $76 \mathrm{kDa}$ and approximately $68 \mathrm{kDa}$, respectively, which correspond to a substantially tetrameric state [Fig. 2(a)]. Moreover, monomer and tetramer bands were observed for streptavidin $\mathrm{C} 1$ via SDS-PAGE when the excess sample was treated at $95^{\circ} \mathrm{C}$ using reducing agents [Fig. 1(c)]. SDS-PAGE analysis of purified streptavidin C1 revealed molecular masss of approximately $18 \mathrm{kDa}$ for the monomer and approximately $76 \mathrm{kDa}$ for the tetramer, which were consistent with those observed by SEC-MALS. We performed $\mathrm{N}$-terminal sequencing to identify the appropriate mature sequences of streptavidin $\mathrm{C} 1$. The result clearly indicated that the $\mathrm{N}$-terminal sequence of the processed protein is ${ }^{34}{ }^{34} \mathrm{ADPR}^{38}$ - (Supplementary Fig. S1). Mass-spectrometric analysis by MALDI-TOF MS of recombinant streptavidin C1 revealed a large peak at $m / z=18667.791$, corresponding to the exact molecular weight of the monomeric protein (Supplementary Fig. S2). The purified antifungal proteins were tested against FOC using a 96-well plate assay. The germination of Fusarium spores was inhibited at a concentration of approximately $10 \mu \mathrm{g} \mathrm{ml}^{-1}$ streptavidin $\mathrm{C} 1$, whereas

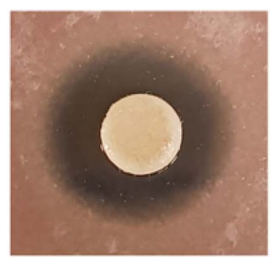

Precipitated fraction

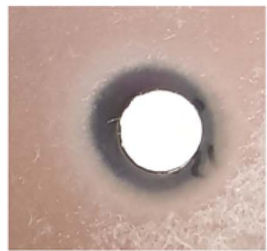

Eluted fraction 1

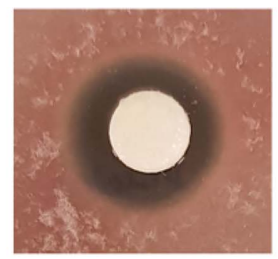

Dialyzed fraction

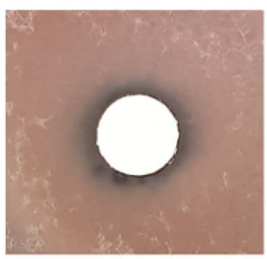

Eluted fraction 2 (a)

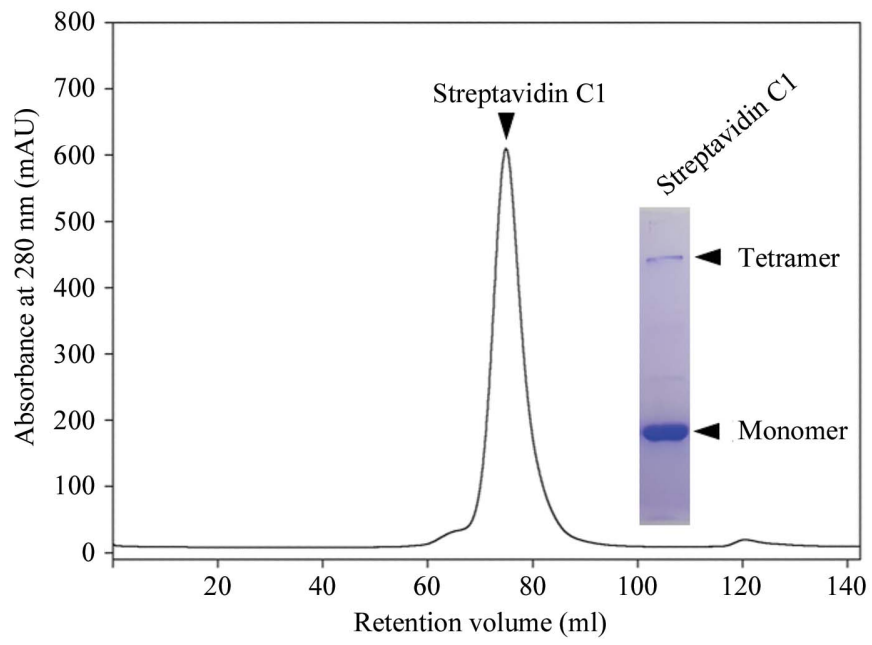

(c)

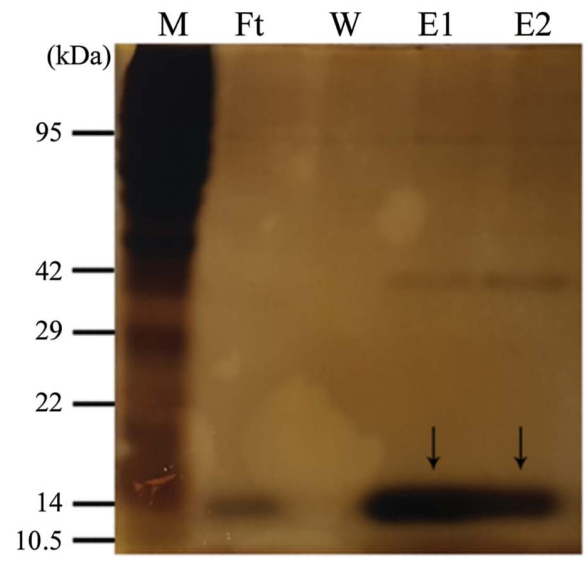

(b)

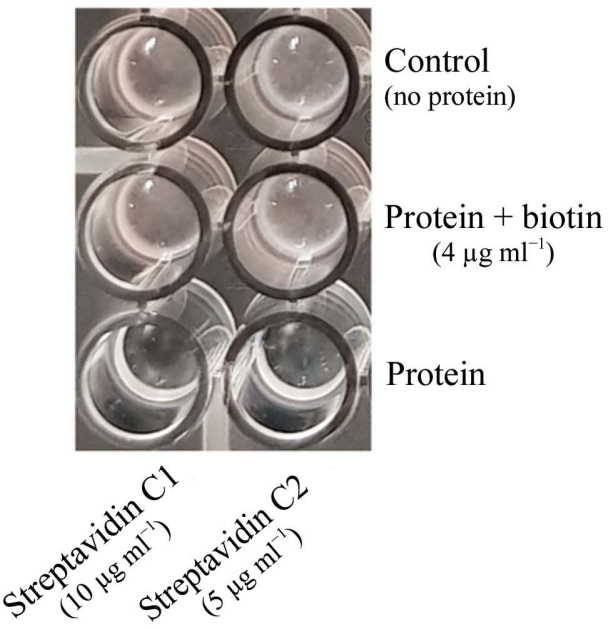

(d)

Figure 1

Purification of an antifungal protein from S. cinnamonensis strain KPP02129. (a) Antifungal activity of semi-purified fractions. (b) Silver-stained SDSPAGE during anion-exchange chromatography. The arrow indicates the purified protein. Lane M, marker; lane Ft, flowthrough fraction; lane W, washing fraction; lane E1, eluted fraction 1; lane E2, eluted fraction 2. (c) Streptavidin C1 was purified via gel-filtration chromatography. Arrowheads indicate the peak and bands corresponding to streptavidin C1. (d) Antifungal activities of the two proteins treated with or without D-biotin against $F$. oxysporum f. sp. cucumerinum. 
streptavidin $\mathrm{C} 2$ exhibited the strongest antifungal activity at a concentration of approximately $5 \mu \mathrm{g} \mathrm{ml}^{-1}$. Furthermore, these antifungal activities disappeared on treatment with $4 \mu \mathrm{g} \mathrm{ml}^{-1}$ D-biotin [Fig. 1(d)]. These results indicate that streptavidin C1 and $\mathrm{C} 2$ as evaluated in the present study are biotin-binding proteins similar to other members of the (strept)avidin family.

\subsection{Overall structure of streptavidin C1}

To gain structural insight into the biotin-binding site and the long C-terminal region of mature streptavidin $\mathrm{C} 1$, the recombinant intact mature form was expressed and purified for crystallization. We determined crystal structures of streptavidin C1 (191 amino acids) in the mature form and as a complex with biotin at 2.1 and $2.5 \AA$ resolution, respectively (Fig. 3). The asymmetric unit comprised one molecule and clearly indicated a tetrameric molecule with $\mathrm{D}_{2}$ symmetry in the crystal [Fig. 3(a)]. Each monomer contains eight antiparallel $\beta$-strands that form a classical $\beta$-barrel structure (Hendrickson et al., 1989; Weber et al., 1989). Mol A and Mol B [as well as Mol C and Mol D in Fig. 3(b)] closely interact to form a stable dimer, and two dimers assemble into a tetramer via hydrophobic interactions involving Leu58, Val80, Trp140 (Mol A) and Trp152 (located on Loop ${ }^{7-8}$ of the neighboring Mol C; Fig. 4, Supplementary Fig. S4). Similar to other streptavidin family members, four sets of interactions are present in the biotin-binding sites. Firstly, a hydrogen-bonding network with biotin is formed by Asn56, Ser60, Tyr76, Ser78 and Asp160. The second set of interactions comprises hydrophobic interactions between biotin and strictly conserved residues (Leu58 in Loop ${ }^{1-2}$, Val80 in Loop ${ }^{3-4}$, Tyr111 in Loop $^{5-6}$, Trp140 in $\beta 7$ and Leu142 in $\left.\beta 7\right)$. Thirdly, residues in the flexible Loop $^{3-4}\left({ }^{80} \mathrm{VGN}^{82}-\right)$ play a pivotal role in the binding of the biotin lid, which is mainly formed with Trp152 (Mol C) in a closed conformation (Fig. 4). Fourthly, the pocket in the tetrameric structure is formed with hydrophobic contributions from the other protomers in the subunit (Mol C and Mol D) [Figs. 3(e) and 3(f)]. Moreover, the long
C-terminal region comprises a short $\alpha$-helix (C-Lid; amino acids 169-179) and an extension C-terminal peptide (ECP; amino acids 180-191) which stretches into the biotin-binding sites of the same monomer. To date, only one mature structure of the streptavidin family with an extension C-terminal peptide has been reported (Le Trong et al., 2006). We did not find electron density for the ECP and C-Lid regions when biotin was bound to the protein, which indicates that these regions are flexible but do not affect the binding ability of biotin. In the mature crystal structure, the C-Lid and ECP mainly interact with His119 in Loop ${ }^{5-6}$ of Mol B' (where ' indicates the symmetric neighboring molecule) and Arg135 of Mol D' (Supplementary Fig. S6); however, the binding site for the ECP is almost identical to that of D-biotin (Fig. 5). Therefore, the ECP sequence $\left({ }^{180}\right.$ VTSANPPAS $\left.{ }^{188}-\right)$ is a newly defined biotin-binding site which reduces the binding ability of (strept)avidin family proteins.

\subsection{Thermal stability of streptavidins $\mathrm{C} 1$ and $\mathrm{C} 2$}

The thermal stabilities of recombinant streptavidins $\mathrm{C} 1$ and $\mathrm{C} 2$ were studied under diverse temperature conditions using an SDS-PAGE system and Tycho NT.6 (NanoTemper Technologies), and were further compared with those of other biotin-binding proteins. Firstly, recombinant streptavidin $\mathrm{C} 1$ heat-treated at $25-80^{\circ} \mathrm{C}$ revealed tetrameric and monomeric forms on SDS-PAGE, whereas recombinant streptavidin C2 showed both forms at $60-80^{\circ} \mathrm{C}$ and only the tetrameric form at $25-50^{\circ} \mathrm{C}$ [Supplementary Figs. S3 $(a)$ and S3(b)]. The proteins only existed in a monomeric form at $90-100^{\circ} \mathrm{C}$. The transition temperatures $\left(T_{\mathrm{r}}\right)$ of streptavidins $\mathrm{C} 1$ and $\mathrm{C} 2$, in which half of the protein is tetrameric and other half is monomeric, in the absence of biotin, were 60 and $70^{\circ} \mathrm{C}$, respectively. The $T_{\mathrm{r}}$ value of streptavidin $\mathrm{C} 1$ is lower than that of streptavidin $\mathrm{C} 2$ and the reported values for streptavidin, bradavidin and tamavidin (Bayer et al., 1996; Nordlund, Hytönen, Laitinen et al., 2005; Takakura et al., 2009). Moreover, streptavidins $\mathrm{C} 1$ and $\mathrm{C} 2$ with D-biotin exhibited thermal stability even at $100^{\circ} \mathrm{C}$ and mostly

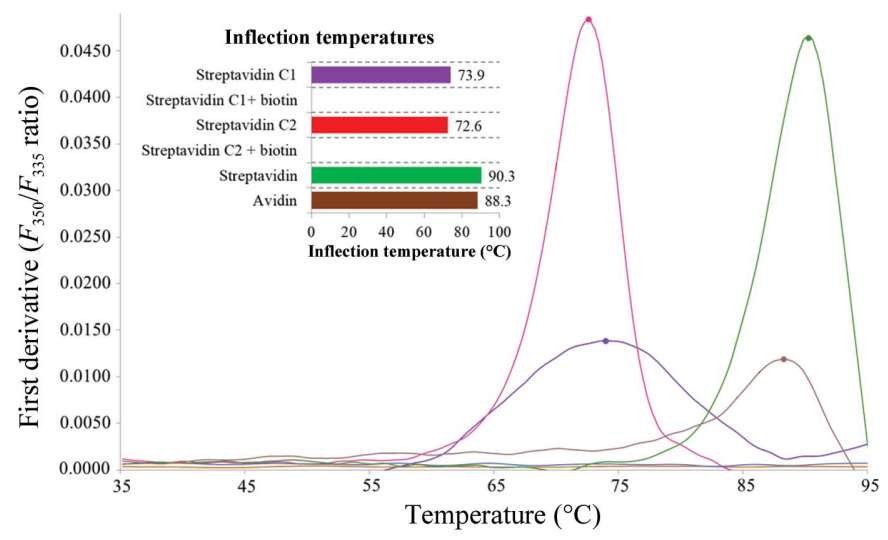

(b)

Figure 2

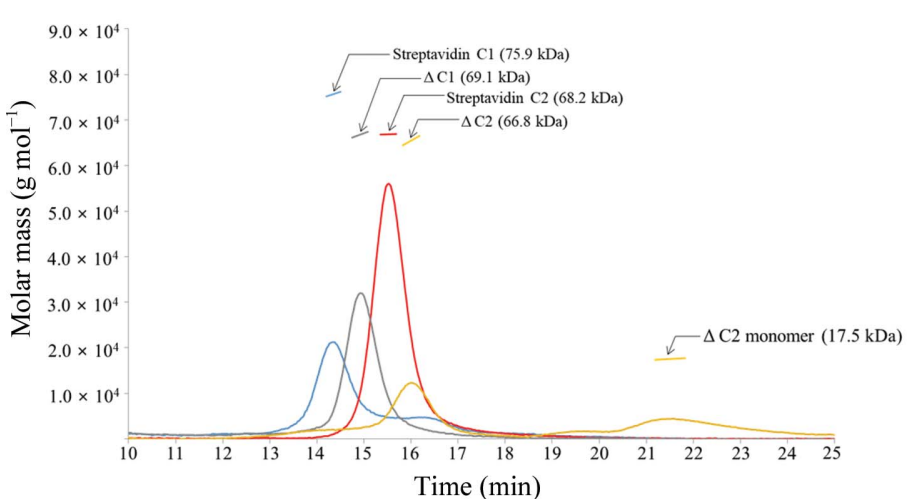

(a) ine), $\Delta \mathrm{C} 1$ (silver line) and $\Delta \mathrm{C} 2$

Molecular mass and thermal stability of biotin-binding proteins. (a) Streptavidin C1 (blue line), streptavidin $\mathrm{C} 2$ (red line), $\Delta \mathrm{C} 1$ (silver line) and $\Delta \mathrm{C} 2$ (yellow line) analyzed by SEC-MALS. All samples were measured at a concentration of $1-2 \mathrm{mg} \mathrm{ml}^{-1}$. The horizontal line represents the measured molar mass. Experimental (MALS) molar-mass values are indicated as arrows. (b) Thermal unfolding profile analysis of streptavidin C1 (violet), streptavidin C2 (red), streptavidin (green) and avidin (brown) with or without biotin from differential scanning fluorimetry. 
remained in the tetrameric form [Supplementary Figs. S3(c) and $\mathrm{S} 3(d)]$. Furthermore, the thermal stabilities of the proteins in the presence of $\mathrm{D}$-biotin and $\beta$-mercaptoethanol were extremely high [Supplementary Figs. S3 $(e)$ and S3 $(f)]$. The disulfide bridge between Cys4 and Cys 83 in Loop $^{5-6}$ is a common distinctive feature in all dimeric avidins analyzed to date (Meir et al., 2012) and thus contributes to their conformational stability. In our proteins no cysteine residues are present, and Pro48 (corresponding to Cys4 of avidin) and Tyr128 (corresponding to Cys83 of avidin) are located at similar positions to those in other members of the avidin family (Supplementary Fig. S4). Therefore, the thermal stabilities of both streptavidins $\mathrm{C} 1$ and $\mathrm{C} 2$ are not affected by the presence of $\beta$-mercaptoethanol, as a strong hydrophobic and hydrogen-bonding interaction is formed instead of a disulfide bridge in the structure (Supplementary Figs. S4 and S5). Secondly, a thermal shift assay was performed using Tycho NT.6 for both mature streptavidins $\mathrm{C} 1$ and $\mathrm{C} 2$ in the apo and biotin-complexed forms [Fig. 2(b)]. The fluorescence signals are plotted as a ratio $(350 / 330 \mathrm{~nm})$ and are used to calculate the midpoint unfolding inflection temperature $\left(T_{\mathrm{i}}\right)$.
Streptavidins $\mathrm{C} 1$ and $\mathrm{C} 2$ demonstrate high thermostability, although their $T_{\mathrm{i}}$ values were lower than those normally observed for proteins of the (strept)avidin family at 73.9 and $72.6^{\circ} \mathrm{C}$, respectively, for the mature form and above $95^{\circ} \mathrm{C}$ for the biotin complexes. Streptavidin and avidin were evaluated, and their $T_{\mathrm{i}}$ values were higher than those of streptavidins $\mathrm{C} 1$ and $\mathrm{C} 2$ ( 90.3 and $88.3^{\circ} \mathrm{C}$ for streptavidin and avidin, respectively).

\subsection{Structural comparison with other (strept)avidin family members}

The sequence identities between streptavidin $\mathrm{C} 1$ (amino acids 1-191) and streptavidin (PDB entry 2bc3; Le Trong et al., 2006) and avidin (PDB entry 5irw; Strzelczyk et al., 2018) are approximately $65.4 \%$ and $32.4 \%$, respectively (Fig. 5, Supplementary Figs. S4 and S5). Both streptavidin C1 and avidin have structural similarity to streptavidin, with rootmean-square (r.m.s.) deviations of 1.10 and $1.33 \AA$, respectively, when $140 \mathrm{C}^{\alpha}$ atoms of streptavidin were aligned in Coot (Emsley et al., 2010; Fig. 5, Supplementary Fig. S5). With

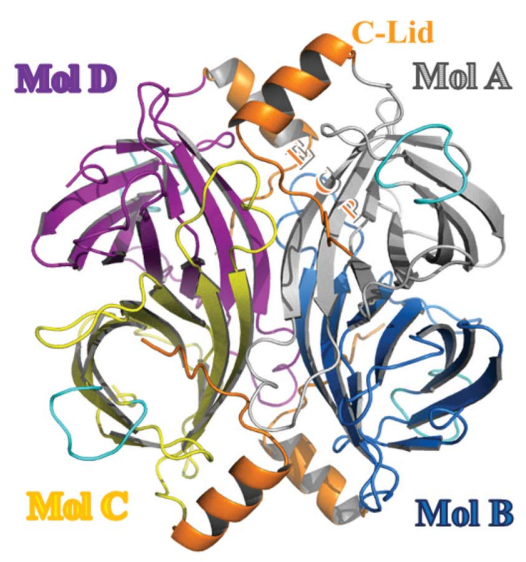

(a)

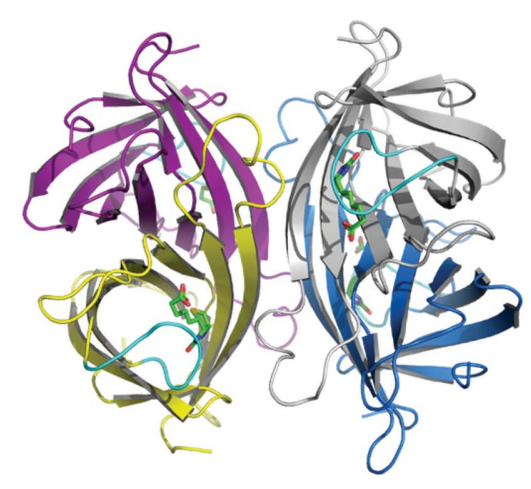

(d)

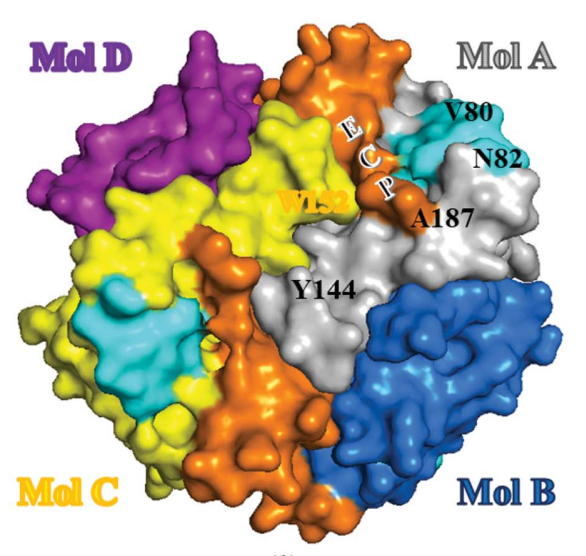

(b)

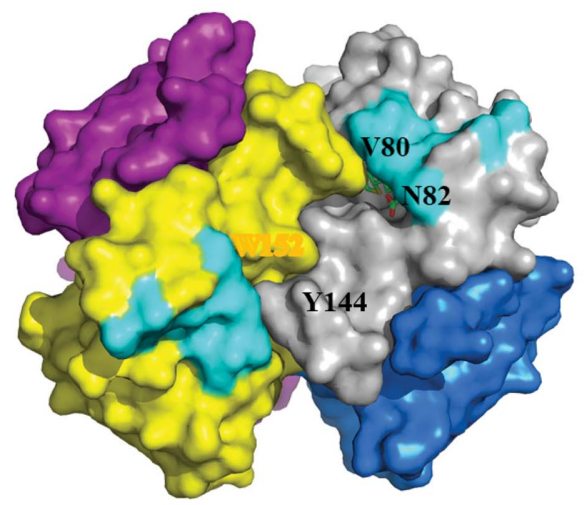

(e)

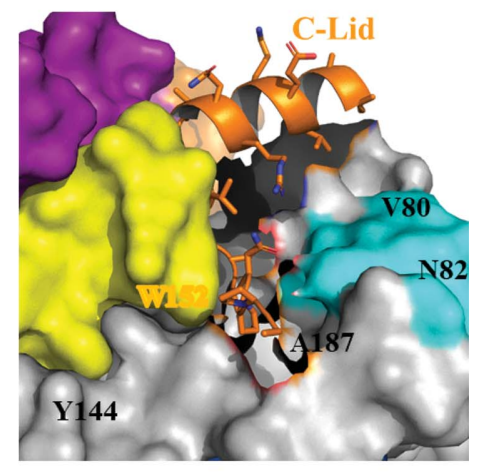

(c)

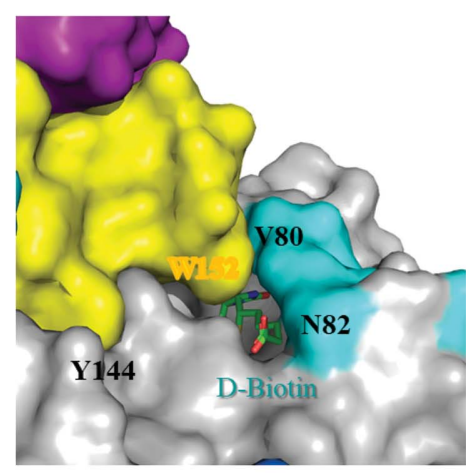

$(f)$

Figure 3

Overall structure of streptavidin C1. (a) Overall tetrameric structure of streptavidin C1. The C-terminal region named C-Lid and the flexible loop region $\left(\right.$ Loop $^{3-4}$ ) are represented as orange and cyan cartoon models, respectively. The monomers are labeled Mol A, Mol B, Mol C and Mol D and are colored gray, marine, yellow and purple, respectively. (c) Surface representation of the streptavidin C1 tetramer. Mol A and Mol B (as well as Mol C and Mol D) closely interact to form a stable dimer, and two dimers assemble into a tetramer. The color code is the same as in $(a)$. (c) Enlarged view of C-Lid and ECP, which interact with various hydrophobic residues such as Leu58, Val80, Trp140, Phe156 (Mol A) and Trp152 (located on Loop ${ }^{7-8}$ of the neighboring Mol C). (d) Overall tetrameric structure of streptavidin $\mathrm{C} 1$ complexed with biotin. Biotin is represented as a ball-and-stick model in green. $(e)$ Surface representation of tetrameric streptavidin $\mathrm{C} 1$ complexed with biotin. $(f)$ Enlarged view of the biotin-binding site of streptavidin $\mathrm{C} 1$. 
regard to the differences in the dimeric avidin structure, as described in Section 3.3, no cysteine residues are present in streptavidin $\mathrm{C} 1$. Tyr128 interacts with several residues at the $\mathrm{N}$-terminus in the crystal structure (Supplementary Fig. S5). Tyr111 in Loop $^{5-6}$ is a specific novel residue that interacts with D-biotin, and in most proteins of the (strept)avidin family this position is occupied by a tryptophan residue, except for tamavidin, which has a phenylalanine at this position. One of the important structural differences between streptavidin $\mathrm{C} 1$ and streptavidin is the ECP region, which is a binding site for D-biotin when superimposed on streptavidin (Fig. 5). Notably, the ECP is located near the D-biotin-binding site. This selfbinding of the ECP from streptavidin $\mathrm{C} 1$ is considerably further from the D-biotin-binding site than that in streptavidin. Most of the amino-acid sequence of the ECP differs from those of streptavidin (Fig. 5). Only two amino acids (-NP-) of

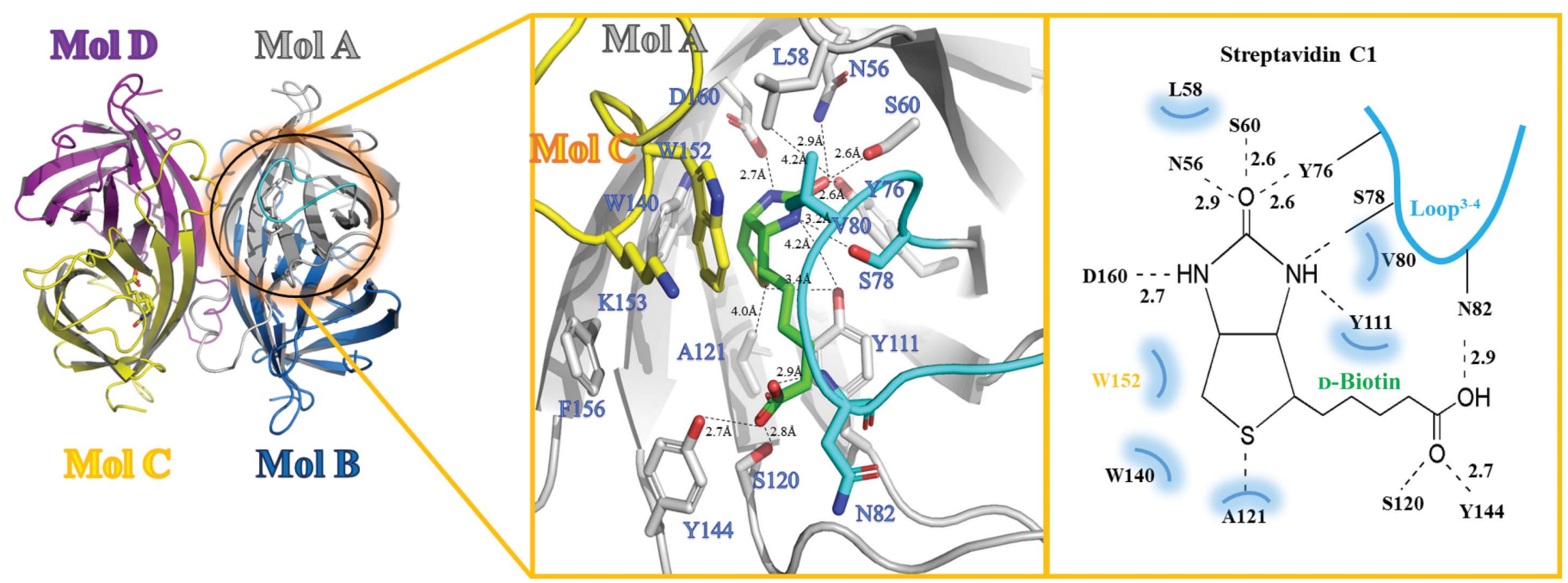

Figure 4

Enlarged view of the streptavidin C1 structure complexed with biotin. The hydrogen-bonding network with biotin is formed by Asn56, Ser60, Tyr76, Ser78 and Asp160, and hydrophobic interactions occur between biotin and strictly conserved residues (Leu58 in Loop ${ }^{1-2}$, Val80 in Loop ${ }^{3-4}$, Tyr111 in Loop $^{5-6}$, Trp140 in $\beta 7$ and Leu142 in $\left.\beta 7\right)$. Residues in the flexible Loop ${ }^{3-4}\left(-{ }^{80} \mathrm{VGN}^{82}-\right)$ play a pivotal role in the binding of biotin, which is mainly formed with Trp152 (Mol C) in a closed conformation.

Figure 5
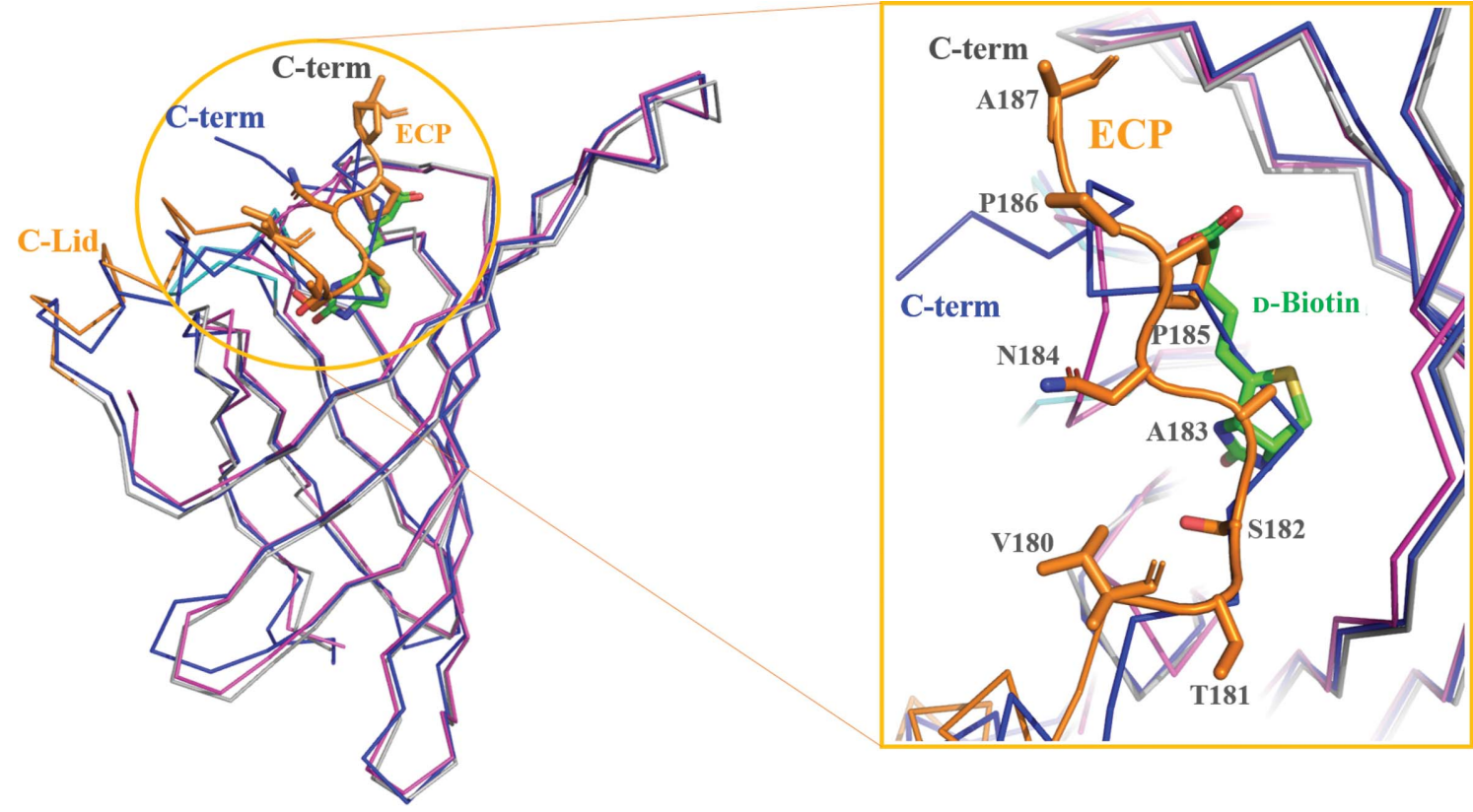

Structural comparison with other (strept)avidin family members. Left: superimposition of the overall structures of streptavidin C1, streptavidin (PDB entry 2bc3) and avidin (PDB entry 5irw). Streptavidin C1, streptavidin and avidin are represented by gray, blue and magenta ribbon models, respectively. The extension C-terminal peptide (ECP) is represented as an orange cartoon model and D-biotin is represented by a green stick model. Right: enlarged view of the ECP (amino acids 180-191), which stretches into the biotin-binding site of the same monomer. When superimposed on streptavidin, the ECP region, which is the binding site for D-biotin, reveals a similar binding site in streptavidin $\mathrm{C} 1$ and streptavidin. Most of the amino-acid sequence of the $\mathrm{ECP}$ differs from that of streptavidin, apart from the $-{ }^{184} \mathrm{NP}^{185}$ - sequence. 


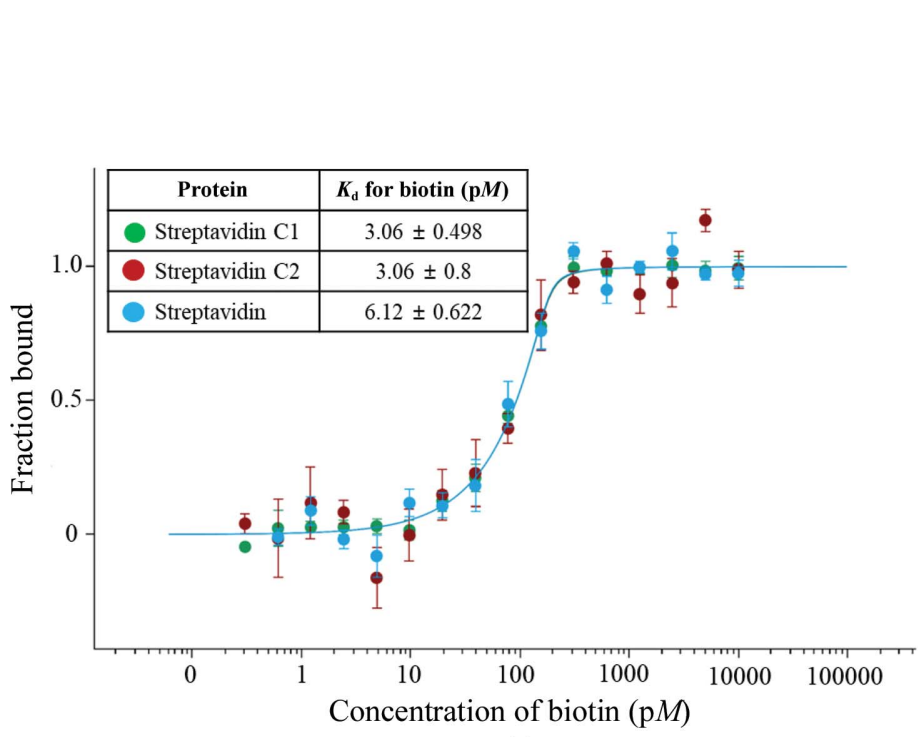

(a)

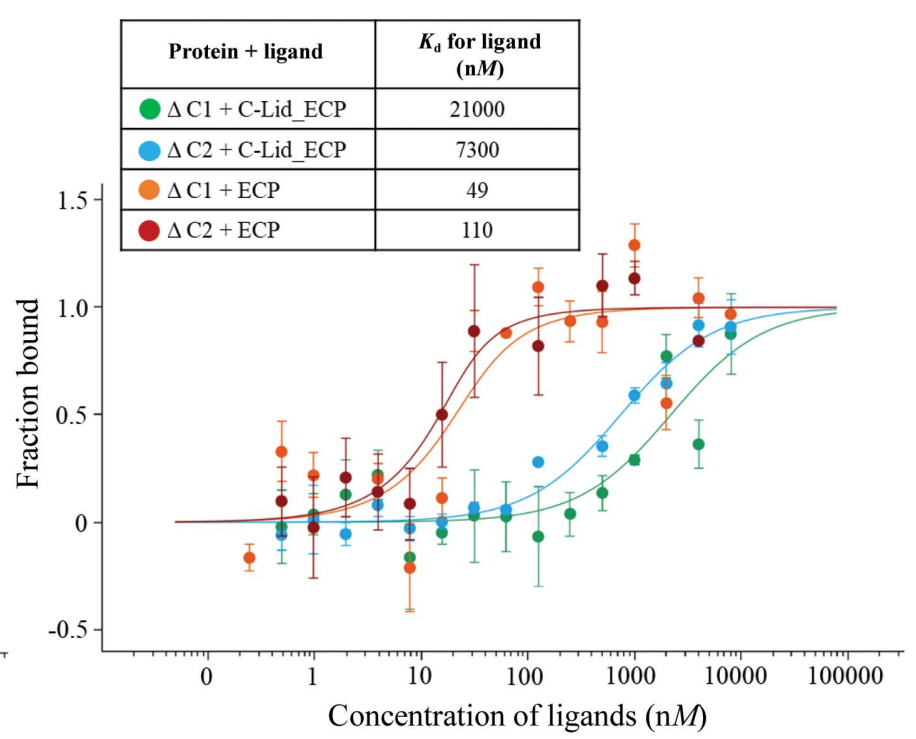

(b)

Figure 6

Direct interactions between fluorescently labeled streptavidins and biotin or labeled C-terminal deletion mutants and ligands measured by microscale thermophoresis (MST). (a) Dose-response curves of streptavidin C1 (green), streptavidin C2 (red) or streptavidin (blue) and the biotin molecule. (b) Dose-response curves of $\triangle \mathrm{C} 1+\mathrm{C}$-Lid_ECP (green), $\triangle \mathrm{C} 2+\mathrm{C}$-Lid_ECP (blue), $\Delta \mathrm{C} 1+\mathrm{ECP}$ (orange) and $\Delta \mathrm{C} 2+\mathrm{ECP}$ (red). The amino-acid sequences of C-Lid_ECP and ECP were designed as $-{ }^{169}$ SAADVEKARQLGVTSANPPASDGE ${ }^{191}$ - and $-{ }^{178}$ LGVTSANPPASDGE $^{191}-$, respectively.

the ECP are similar to those in streptavidin. Considering the sequence and structural similarities, we suggest that this ECP sequence $\left(-{ }^{180}\right.$ VTSANPPAS $\left.{ }^{188}-\right)$ is a newly defined biotinbinding site which reduces the binding ability of the (strept)avidin family proteins, with the $-\mathrm{NP}$ - sequence possibly acting as the key sequence in this binding site. To effectively reduce the biotin-binding ability, we will further design a peptide based on our structural analysis of streptavidin $\mathrm{C} 1$.

\subsection{Affinity of streptavidins for binding to biotin}

The interaction between streptavidin $\mathrm{C} 1$ or two deletion mutants $(\Delta \mathrm{C} 1$, amino acids $1-161$, and $\Delta \mathrm{C} 2$, amino acids $1-$ $158)$ and D-biotin was measured using microscale thermophoresis (MST), a novel method for the quantitative analysis of protein interactions in free solution. Recombinant streptavidins $\mathrm{C} 1$ and $\mathrm{C} 2$ and streptavidin proteins (target concentration of $200 \mathrm{p} M$ ) were labeled with fluorescent dye and incubated with increasing concentrations of biotin (0.3052$10000 \mathrm{pM}$ ) [Fig. 6(a)]. The $K_{\mathrm{d}}$ of biotin binding to recombinant streptavidin $\mathrm{C} 1$ was about $3.06 \pm 0.498 \mathrm{p} M$. The apparent $K_{\mathrm{d}}$ values of streptavidin C2 and streptavidin for D-biotin were $3.06 \pm 0.8$ and $6.12 \pm 0.622 \mathrm{p} M$, respectively [Fig. 6(a)]. These results suggest that streptavidins $\mathrm{C} 1$ and $\mathrm{C} 2$ have an extremely high affinity for D-biotin, similar to that of streptavidin. In this study, we constructed two deletion mutants, $\Delta \mathrm{C} 1$ and $\Delta \mathrm{C} 2$, in order to identify the binding affinities of C-Lid_ECP and ECP, respectively [Fig. $6(b)]$. The results reveal that the ECP sequence has a higher binding affinity than the C-Lid_ECP sequence for $\Delta \mathrm{C} 1$ and $\Delta \mathrm{C} 2$. The $K_{\mathrm{d}}$ values of C-Lid_ECP and ECP for $\Delta \mathrm{C} 1$ are approximately 21000 and $49 \mathrm{n} M$, respectively. The $K_{\mathrm{d}}$ values of $\Delta \mathrm{C} 2$ are about $7300 \mathrm{n} M$ and $110 \mathrm{n} M$, respectively [Fig. 6(b)]. We suggest that the ECP sequence contributes greatly to the binding to streptavidin $\mathrm{C} 1$ or $\mathrm{C} 2$ compared with C-Lid_ECP. Therefore, the ECP sequence $\left(-{ }^{180}\right.$ VTSANPPAS $\left.{ }^{188}-\right)$ is a newly defined biotin-binding site which reduces the binding ability of (strept)avidin family members. The newly identified streptavidin C1 will help to develop an engineered tetrameric streptavidin with reduced biotin-binding capability and of other desirable biomaterial tools.

\section{Conclusion}

This study showed that streptavidins $\mathrm{C} 1$ and $\mathrm{C} 2$, which are new antifungal proteins from $S$. cinnamonensis strain KPP02129, could inhibit mycelial growth of F. oxysporum $\mathrm{f}$. sp cucumerinum. We assessed the crystal structures of streptavidin $\mathrm{C} 1$ in the mature form and as a complex with biotin at 2.1 and $2.5 \AA$ resolution, respectively. We also measured the thermal stability and binding affinity of streptavidins $\mathrm{C} 1$ and $\mathrm{C} 2$ by MST. Interestingly, we found that the ECP sequence $\left(-{ }^{180}\right.$ VTSANPPAS $\left.{ }^{188}-\right)$ is a newly defined biotin-binding site which reduces the binding ability of (strept)avidin family members. The novel streptavidin $\mathrm{C} 1$ could help in the development of an engineered tetrameric streptavidin with a reduced biotin-binding capacity as well as other biomaterial tools.

\section{Acknowledgements}

We would like to thank the staff of BL-11C at PLS in South Korea, BL-1A at Photon Factory and BL44XU at SPring- 8 in Japan for allowing us to use their excellent facilities and for their assistance with X-ray data collection. 


\section{Funding information}

SK was supported by grant No. 2019R1I1A1A01056 from the National Research Foundation of Korea. KYH was supported by Korea University Funds. This work was supported by project grants (Nos. 2020R1A2C2005670 and 2018M3A9F3055925) from the National Research Foundation funded by the Ministry of Science of Korea and the Next K2 project of Kyung-Nong Corp.

\section{References}

Avraham, O., Meir, A., Fish, A., Bayer, E. A. \& Livnah, O. (2015). J. Struct. Biol. 191, 139-148.

Bayer, E. A., Ehrlich-Rogozinski, S. \& Wilchek, M. (1996). Electrophoresis, 17, 1319-1324.

Bayer, E. A., Kulik, T., Adar, R. \& Wilchek, M. (1995). Biochim. Biophys. Acta, 1263, 60-66.

Chaiet, L. \& Wolf, F. J. (1964). Arch. Biochem. Biophys. 106, 1-5.

Chen, V. B., Arendall, W. B., Headd, J. J., Keedy, D. A., Immormino, R. M., Kapral, G. J., Murray, L. W., Richardson, J. S. \& Richardson, D. C. (2010). Acta Cryst. D66, 12-21.

DeMonte, D., Drake, E. J., Lim, K. H., Gulick, A. M. \& Park, S. (2013). Proteins, 81, 1621-1633.

Diamandis, E. P. \& Christopoulos, T. K. (1991). Clin. Chem. 37, 625636.

Emsley, P., Lohkamp, B., Scott, W. G. \& Cowtan, K. (2010). Acta Cryst. D66, 486-501.

Green, N. M. (1990). Methods Enzymol. 184, 51-67.

Helppolainen, S. H., Nurminen, K. P., Määttä, J. A., Halling, K. K., Slotte, J. P., Huhtala, T., Liimatainen, T., Ylä-Herttuala, S., Airenne, K. J., Närvänen, A., Jänis, J., Vainiotalo, P., Valjakka, J., Kulomaa, M. S. \& Nordlund, H. R. (2007). Biochem. J. 405, 397-405.

Hendrickson, W. A., Pähler, A., Smith, J. L., Satow, Y., Merritt, E. A. \& Phizackerley, R. P. (1989). Proc. Natl Acad. Sci. USA, 86, 21902194.

Howarth, M., Chinnapen, D. J.-F., Gerrow, K., Dorrestein, P. C., Grandy, M. R., Kelleher, N. L., El-Husseini, A. \& Ting, A. Y. (2006). Nat. Methods, 3, 267-273.

Hytönen, V. P., Nordlund, H. R., Hörhä, J., Nyholm, T. K., Hyre, D. E., Kulomaa, T., Porkka, E. J., Marttila, A. T., Stayton, P. S., Laitinen, O. H. \& Kulomaa, M. S. (2005). Proteins, 61, 597-607.

Keinänen, R. A., Wallén, M. J., Kristo, P. A., Laukkanen, M. O., Toimela, T. A., Helenius, M. A. \& Kulomaa, M. S. (1994). Eur. J. Biochem. 220, 615-621.

Laitinen, O., Hytönen, V., Nordlund, H. \& Kulomaa, M. (2006). Cell. Mol. Life Sci. 63, 2992-3017.

Laitinen, O. H., Nordlund, H. R., Hytönen, V. P. \& Kulomaa, M. S. (2007). Trends Biotechnol. 25, 269-277.
Langer, G., Cohen, S. X., Lamzin, V. S. \& Perrakis, A. (2008). Nat. Protoc. 3, 1171-1179.

Lee, J. M., Kim, J. A., Yen, T.-C., Lee, I. H., Ahn, B., Lee, Y., Hsieh, C.-L., Kim, H. M. \& Jung, Y. (2016). Angew. Chem. 128, 3454-3458.

Lesch, H. P., Kaikkonen, M. U., Pikkarainen, J. T. \& Ylä-Herttuala, S. (2010). Expert Opin. Drug Deliv. 7, 551-564.

Le Trong, I., Humbert, N., Ward, T. R. \& Stenkamp, R. E. (2006). J. Mol. Biol. 356, 738-745.

Liebschner, D., Afonine, P. V., Baker, M. L., Bunkóczi, G., Chen, V. B., Croll, T. I., Hintze, B., Hung, L.-W., Jain, S., McCoy, A. J., Moriarty, N. W., Oeffner, R. D., Poon, B. K., Prisant, M. G., Read, R. J., Richardson, J. S., Richardson, D. C., Sammito, M. D., Sobolev, O. V., Stockwell, D. H., Terwilliger, T. C., Urzhumtsev, A. G., Videau, L. L., Williams, C. J. \& Adams, P. D. (2019). Acta Cryst. D75, 861-877.

Livnah, O., Bayer, E. A., Wilchek, M. \& Sussman, J. L. (1993). Proc. Natl Acad. Sci. USA, 90, 5076-5080.

Määttä, J. A., Helppolainen, S. H., Hytönen, V. P., Johnson, M. S., Kulomaa, M. S., Airenne, T. T. \& Nordlund, H. R. (2009). BMC Struct. Biol. 9, 63.

McCoy, A. J., Grosse-Kunstleve, R. W., Adams, P. D., Winn, M. D., Storoni, L. C. \& Read, R. J. (2007). J. Appl. Cryst. 40, 658-674.

Meir, A., Bayer, E. A. \& Livnah, O. (2012). J. Biol. Chem. 287, 1795117962.

Meir, A., Helppolainen, S. H., Podoly, E., Nordlund, H. R., Hytönen, V. P., Määttä, J. A., Wilchek, M., Bayer, E. A., Kulomaa, M. S. \& Livnah, O. (2009). J. Mol. Biol. 386, 379-390.

Murshudov, G. N., Skubák, P., Lebedev, A. A., Pannu, N. S., Steiner, R. A., Nicholls, R. A., Winn, M. D., Long, F. \& Vagin, A. A. (2011). Acta Cryst. D67, 355-367.

Nordlund, H. R., Hytönen, V. P., Hörhä, J., Määttä, J. A., White, D. J., Halling, K., Porkka, E. J., Slotte, J. P., Laitinen, O. H. \& Kulomaa, M. S. (2005). Biochem. J. 392, 485-491.

Nordlund, H. R., Hytönen, V. P., Laitinen, O. H. \& Kulomaa, M. S. (2005). J. Biol. Chem. 280, 13250-13255.

Otwinowski, Z. \& Minor, W. (1997). Methods Enzymol. 276, 307-326.

Strzelczyk, P., Plażuk, D., Zakrzewski, J. \& Bujacz, G. (2018). Molecules, 21, 1270.

Takakura, Y., Tsunashima, M., Suzuki, J., Usami, S., Kakuta, Y., Okino, N., Ito, M. \& Yamamoto, T. (2009). FEBS J. 276, 1383-1397.

Taskinen, B., Zmurko, J., Ojanen, M., Kukkurainen, S., Parthiban, M., Määttä, J. A., Leppiniemi, J., Jänis, J., Parikka, M., Turpeinen, H., Rämet, M., Pesu, M., Johnson, M. S., Kulomaa, M. S., Airenne, T. T. \& Hytönen, V. P. (2013). PLoS One, 8, e77207.

Weber, P. C., Ohlendorf, D. H., Wendoloski, J. \& Salemme, F. (1989). Science, 243, 85-88.

Winn, M. D., Ballard, C. C., Cowtan, K. D., Dodson, E. J., Emsley, P., Evans, P. R., Keegan, R. M., Krissinel, E. B., Leslie, A. G. W., McCoy, A., McNicholas, S. J., Murshudov, G. N., Pannu, N. S., Potterton, E. A., Powell, H. R., Read, R. J., Vagin, A. \& Wilson, K. S. (2011). Acta Cryst. D67, 235-242. 